\title{
THE PROTECTION OF LAND RIGHTS IN ETHIOPIA
}

\section{Montgomery Wray Witten}

\author{
Former Dean \\ Mekelle University, Law Faculty \\ Mekelle, Tigray \\ Ethiopia
}

e-mail: wrayw2@yahoo.com

\section{SUMMARY}

\section{The Protection of Land Rights in Ethiopia}

Protection of land rights takes place within a complex interconnected environment of constantly changing domestic institutions and organizations at the federal, state and local levels of society. Usually these institutions and organizations function imperfectly, are the subject of a variety of ongoing reforms, and are poorly understood by those who seek to change them. These statements are as true of rich countries as of poor, but poverty does matter. This paper frames the Ethiopian environment within an Ecology of Land Rights Protection, presents examples of the current mixture of outcomes, and concludes with observations about the work of the Mekelle University Law Faculty in improving human rights protection.

Key Words: Land Rights, Federal Laws and Regional Laws, Tigray, Land Registration and Certification, Local Government 


\section{LAND RIGHTS: DELINEATION}

For many people, land rights and their protection are central to life. But what are 'land rights'? More particularly, in the setting of this seminar, what human rights are recognized to land, or related to land?

The international farmers movement La Via Campesina ${ }^{1}$ has often articulated the need for a human right to land, particularly for subsistence farmers. Just as clearly they have demonstrated that there is none recognized internationally.

Instead, what we find are a variety of general and specific (e.g., for women ${ }^{2}$ ) human rights related to land (or the more ambiguous 'home' or 'property' ${ }^{\prime 3}$ which may or may not include land). These international rights related to land are all in the nature of more general human rights to due process of $\mathrm{law}^{4}$, equal protection of law $^{5}$, and non-discrimination. ${ }^{6}$ That is, if a person has land or if some right to land is recognized (as when a government-sponsored land redistribution occurs), then the right to land should not be taken, lost or denied without due process and equal protection of law, and no other recognized rights should be dependent on whether the person has land or not.

However, domestic land rights are rarely affected by international instruments. We must look to domestic systems. In Ethiopia, both by incorporation of international agreements (Article 9.4) and inclusion of specific provisions (often identical in language to the international instruments), the current Constitution ${ }^{7}$ includes both

\footnotetext{
${ }^{1}$ See, www.viacampesina.org

${ }^{2}$ Convention on Elimination of All Forms Of Discrimination Against Women (CEDAW) Article 14.2(g).

${ }^{3}$ Universal Declaration of Human Rights (UDHR), Articles 12 and 17, respectively

${ }^{4}$ UDHR Art. 8, 17; International Convention on Civil and Political Rights (ICCPR) Art. 17, 26.

${ }^{5}$ UDHR Art. 7, 17; ICCPR Art. 17, 26.

${ }^{6}$ UDHR Articles 2, 7, 17; ICCPR Art. 17, 26.

${ }^{7}$ Proclamation No. 1/1995. It should be remembered that the Amharic version is the official version (Article 106).
} 
general human rights related to land, i.e., to due process, equal protection and nondiscrimination (Article 25), and specific rights for women (Article 35.5) and other groups (Article 40).

But, quite unusually among the nations of the world, Ethiopia's Constitution also grants actual rights to rural $^{8}$ land (Article 40).

Of course, as soon as that is said, it is necessary to ask what such a right entails. And, more generally, in order to provide the most elementary basis for this paper, we must distinguish between different 'rights' in land. For the bizarre and diverse nature of land rights, and the ability to fragment them in novel ways, appears to be limited only by failure of human imagination. In addition, each of these rights may be held by one or more different parties. For example, the right to use the surface ${ }^{9}$ may be owned by one party, granted conditionally to another, leased on to several others, future interests assigned to yet others, and taken at any time in whole or part by the State. Thus, what is sometimes called the 'bundle' of land rights is, in almost all cases, fragmented and distributed over many holders so that an individual's rights in a particular parcel of land are actually quite restricted and limited by the rights of the State and other parties. Conflicts between all those holders of rights are, of course, common.

Similarly, the current laws establishing and allocating land rights in Ethiopia distribute those rights among various holders. Most fundamentally, the Ethiopian Constitution places certain rights in the hands of the State:

The right to ownership of rural and urban land, as well as of all natural resources, is exclusively vested in the State and in the peoples of Ethiopia.

\footnotetext{
${ }^{8}$ This paper focuses on rural and peri-urban land because urban land is under a different administrative system and almost all land in Ethiopia falls outside the urban category.

${ }^{9}$ Never mind rights to use the air above and subsurface, or the right to decide what use may be made of any of these - likely to be held by a local government.
} 
But then reserves to three classes of people specific rights to land:

40.4. Ethiopian peasants have the right to obtain land without payment and the protection against eviction from their possession. The implementation of this provision shall be specified by law;

40.5. Ethiopian pastoralists have the right to free land for grazing and cultivation as well as the right not to be displaced from their own lands. The implementation shall be specified by law;

40.6. Without prejudice to the right of Ethiopian Nations, Nationalities, and Peoples to the ownership of land, government shall ensure the right of private investors to the use of land on the basis of payment arrangements established by law. Particulars shall be determined by law.

It is important to note that each of these rights is hedged by the last provision in each paragraph, that the particulars of each right are to be determined by law. To date, these Constitutional provisions have been further delineated by two Federal laws ${ }^{10}$ and the different laws and regulations of each of the Federal States (see below).

By the Federal land laws, the Federal government's Constitutional authority to proclaim laws related to land (Article 51.5) has been partially delegated, within specific though broad guidelines, to the States. ${ }^{11}$ This has allowed significant differences in State laws. The Constitution also allocates the authority to administer land and other natural resources in accordance with Federal laws directly to the States (Article 52.6).

But, so far, how much the basic Constitutional rights may legally be modified by such laws is quite untested in the courts. For example, the right of children to inherit rural land has been both specifically

\footnotetext{
${ }^{10}$ Proclamation No. 89/1997, Rural Land Administration Proclamation Of The Federal Democratic Republic of Ethiopia (FDRE); and Proclamation No. 456/2005, FDRE Rural Land Administration and Land Use Proclamation.

${ }^{11}$ As can be seen by the fact that three States, Amhara, Oromia and Tigray, passed laws before authorized, the first Federal law was clearly an effort to catch up with State initiatives.
} 
acknowledged in the successive Federal land laws ${ }^{12}$ and subject to limitations in State laws. ${ }^{13}$ As a specific example, the laws of Tigray State both assure and limit inheritance of land. The State's goal is clearly to balance increased certainty of an adequate payback period and, thus, the holder's investment in land (Gebremehdin, B., 2003; Atwood, D., 1990; Barrows, R. and Roth, M., 1990), with the social welfare principle that the most needy descendants obtain the parents' very limited land. The need to balance such competing policy principles is prevalent in land rights legislation, but when eventually challenged the basic right may be determined by the courts to limit policy choices.

\section{PROTECTION OF LAND RIGHTS: A SCHEMATIC INTRODUCTION}

From the Land In Africa Conference (Quan, J., Tan, S., et al, 2005), we may take some lessons: economy, history, perspective, alignment of interests, and structural details all matter in the protection of land rights. In Tigray State, northern Ethiopia, where the detailed research on which this paper is based has been centered, and in the literature concerning land rights and our less in-depth research in other parts of Ethiopia, we have found the same to be true.

A) Despite relatively rapid economic growth since 1991, Ethiopia remains one of the very poorest nations on earth and, within Ethiopia, Tigray State is the poorest area of the settled rural population. Ethiopia has 70 million people and a Human Development Index placing it 170th out of 177 nations (UNDP 2005). Tigray has

\footnotetext{
12 Proclamation No. 89/1997, Rural Land Administration Proclamation Of The Federal Democratic Republic of Ethiopia (FDRE), Article 2.3; and Proclamation No. 456/2005, FDRE Rural Land Administration and Land Use Proclamation, Article 8.5.

${ }^{13}$ State laws and regulations vary greatly. Tigray State adopted Proclamation No. 23/1997, Rural Land Utilization Proclamation of The Tigray National Regional State, replaced in 2004, and Rural Land Utilization, Investment, Agricultural and Natural Resources Development Regulation, Proclamation No. 15/2001/02, also with amendments. State proclamations issued before Federal devolution were legitimized by the Federal land laws inclusion of "savings clauses" that recognize earlier State laws that conform to specific guidelines.
} 
4 million people, of whom $85 \%$ are smallholder subsistence farmers; of these $75 \%$, the largest proportion in any settled farming area in Ethiopia, do not have enough land to produce a living (EEPRI 2001).

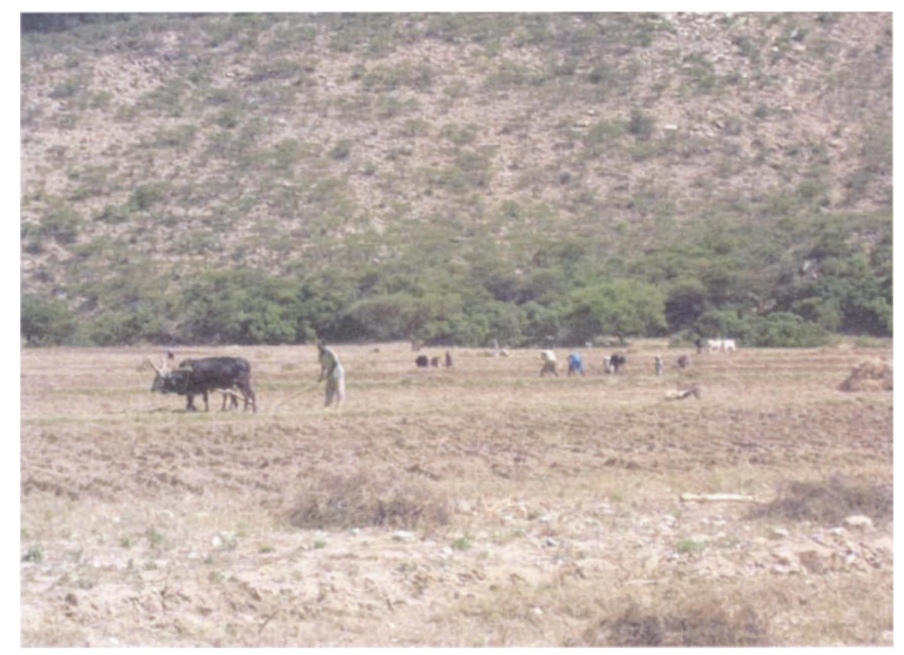

Smallholders working their land in Geba valley, Tigray (photo by J. Nyssen)

B) Focusing on land rights, one of the striking differences between Ethiopia and other nations is its recent history. The current forms of land rights, and the systems for protecting them, exist today as the most recent iteration of a sequence of radical changes. Ancient customary laws were amended by, inter alia, Emperor Haile Selassie's mid-twentieth century efforts at modernization through introduction of a Constitution and a new Civil Code, and then again by the Derg (the Soviet Union-backed military dictatorship from 1974 to 1991) Constitution and proclamations. The latter nationalized all land, redistributed the majority of rural land, and, in the process, created new forms of land rights and, quite probably, extinguished almost all former land rights. ${ }^{14}$ If we were to consider

${ }^{14}$ The Provisional Military Government of Ethiopia (1975), Proclamation No.31 of 1975, A Proclamation to Provide for the Public Ownership of Rural Lands, Addis Ababa. Whether the "extinguished" rights to interests in land might be revived, 
the protection of land rights during that transformation period, we would find, particularly from the perspective of the establishment, many people's land rights badly abused. ${ }^{15}$ But today - thirty years after the Derg transformation - the problems entailed by overlapping historical and regional land tenure systems in other nations ${ }^{16}$ are relatively mild in Ethiopia.

C) There are many perspectives from which the success of a land rights protection system may be judged quite differently, e.g., those of the poor, rich, rural or urban citizens, as well as the administrators', politicians and 'disinterested' observers. But the perspective of the economic historian Douglass North (North, D., 1990), in terms of institutions, both formal and informal, provides particularly penetrating insights to the protection of land rights.

Simply put, North uses the word 'institutions' to mean 'the rules of the game', rather than organizations, with formal rules including constitution, laws and regulations and informal rules including a variety of other rule-like constraints on behavior, such as customs, traditions and even habits. Of particular importance is the finding that formal rules are relatively easy to change while informal rules are much harder. Using these concepts, 'administrative discretion' may be understood as one important place where formal and informal rules meet, sometimes producing innovative solutions to unforeseen problems, as intended, but also providing fertile grounds for various forms of abuse of power.

either politically or through judicial action, is unknown. Efforts in other countries, from Kenya to the USA, have had very mixed results. In addition, for example, some villages in Tigray have reallocated land to the church (e.g., in Felig Daro tabia, Tigray State, a plot of traditionally irrigated land that is leased to a local farmer each year by auction), perhaps reducing pressure to reinstating prior rights.

${ }^{15}$ In addition, the Derg prohibited the renting out of land, and other transactions (sales, mortgages, sharecropping and hiring in labor) were severely restricted. The current FDRE Constitution reinstates some (renting land in and out, sharecropping, and hiring in labor) but not all (sales and mortgages are still prohibited) of these rights. There has been some debate about how extensive the changes really were (Marcus, H. 1994).

${ }^{16}$ E.g., Cousins, B. and Claassens, A., 2006, document the complicated and contentious results in South Africa. 
D) Alignment of interests is not always possible. To demonstrate this, let us consider rural Tigray ${ }^{17}$, where demand far outstrips available land. Past land redistributions - in some villages in Tigray as many as a dozen times between 1974 and 1989, 'trying to get it right' - created uncertainty, undercut investment in land, and created hard feelings. The land registration and certification undertaken in the mid-90s were desired by farmers to clearly mark the official end of redistributions.

But, when massive land redistributions were stopped, access to land suddenly changed from primarily ${ }^{18}$ village allocation to mostly family allocation. And, because family land holdings were already too small, many young people reaching the age when they should receive access to rural land found none available either from their family or the village. They saw registration and certification as the end of any possibility of obtaining land, and made their disquiet known.

Their demand for land, together with improved malaria control, eventually formed the primary motive force behind the government's recent opening of unsettled land along Ethiopia's western border to new voluntary settlements. In this way, over time, the alignment of interests has evolved and, by some measures, improved, but not without large social changes and costs.

E) Comparison of the Tigray land rights protection efforts with the subsequent efforts of the Amhara State to implement a similar program illuminates how systemic differences arise. As is more fully described below, the 'Tigray Model' of land rights preservation is embedded in the village local government. When Amhara State subsequently began a similar system, fresh in the minds of the citizens were the more recent (1996/1997, compared to 1989 in Tigray)

\footnotetext{
${ }^{17}$ There is evidence from family land holding size that the conditions in other areas of Ethiopia are not as pressured (EEA/EEPRI, 2002; Mersha, G. and wa Githinji, M., 2005).

${ }^{18}$ As discussed below, some land also still returns to the village local government and is available for distribution to adults returning to the village and youths coming of age.
} 
and probably punitive (Hoben, A., 2001; Adal, Y., 1997; Debele, B., 1997; Ege, S., 1997) land redistributions that had left many people afraid of the local governments that had administered them. Therefore $^{19}$, the administrative portion of the Amhara State land rights protection system was set up as an independent line organization, intentionally removing land issues from the grasp of local government. Whether this change in the 'Tigray Model' will be followed in Tigray is not clear. Some of the new parallel structure has recently been put in place in Tigray, but the benefits of the system operating through the local government, described below, are also well appreciated.

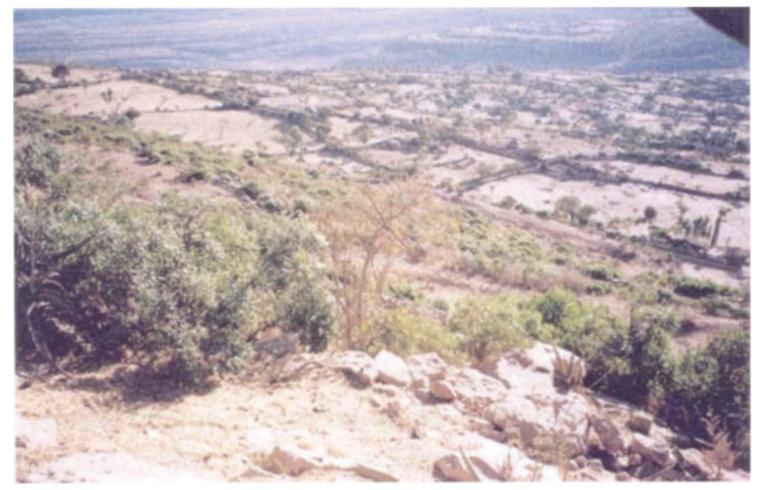

Traditional agroforestry trees bordering farm plots in Tigray (photo by J. Nyssen)

More generally, this is but one structural difference among a very large possible number. ${ }^{20}$ Still, though land rights are handled in very different ways in different nations ${ }^{21}$, all land rights protection

\footnotetext{
19 Personal communication, Legal Advisor to the President of Amhara State, February 2005.

${ }^{20}$ The definition of 'rural land administration' in the current Federal land law recognizes this: "...means a process whereby rural land holding security is provided, land use planning is implemented, disputes between rural land holders are resolved and the rights and obligations of any rural land holder are enforced, and information on farm plots and grazing land holders are gathered, analyzed and supplied to users." Proclamation 456/2005, Section 2.2.

${ }^{21}$ The current efforts just within the European Union to reduce institutional barriers to land transactions has also found this. Personal interview with UK member of the
} 
systems seem to entail a combination of institutions and organizations in the following functionally defined niches. We call this an Ecology of Land Rights Protection ${ }^{22}$ :

- Identification of a piece of land: This may be done with simple (and often cheap) or sophisticated (and usually more expensive) technologies. For example, a piece of land within a small community may be defined simply by the name of the holder or the names of the neighbors; it may be marked on the ground (e.g., with natural landmarks, stone walls, steal pins, or fabricated monuments); or it may be described with various types of more or less accurate measurements so that the land can be located on the ground when there is a dispute.

- Creation of rights: Over time, various rights in the piece of land are created and allocated to individuals, groups, the State, and other levels of government. Various social institutions and organizations create the initial rights, and the many limitations on them (e.g., royal or State grants, Federal and State laws, local land-use plans, community bylaws or even customs), and their allocation. Cognizance of all sources of rights is important if their interaction is to be predictable.

- Transformation of rights: Changes in the initial rights, and the person or persons or organizations holding them, occur through private intentional transactions (e.g., sales or leases) but also through more complex transactions (e.g., enactment of new laws, government regulation or takings, or adjudication of divorce or inheritance or incompetence or dissolution) accomplished through one, or some combination of, forums - legislative, administrative or judicial; government or private sector; local and community-based or distant and centralized, cheap or costly.

- Preservation of evidence of the original rights and the transformations (documentary or witnesses): For example, the original of documents, or a copy or certified summary, may be

Commission, February 2006. Official websites of nations and States are particularly useful for understanding the different functions of the essential components, e.g., http://www.ros.gov.uk/index.html (Scotland); http://www.landregistry.gov.uk.html (England and Wales).

${ }^{22}$ The Ecology relies heavily on Haile, M., Witten, W., et al, 2005. 
lodged in collections (one or more, publicly accessible or not), kept safe from natural elements and human tampering, and, often, helpfully indexed by the names of the actors, the dates of the transactions or events, the piece(s) of land affected, or all of these. The collection may be entrusted to the interested parties, the State, private enterprise, or a combination. Preserving the evidence of aging witnesses is more difficult.

- Registration of 'title': The rights held by various parties in the piece of land may ${ }^{23}$ be recorded in some form. But it is essential to understand that 'title' is a legal conclusion, based on available evidence, interpreted in light of current rules - a conclusion that may be in error or, even though never actually in error, may change from time to time as a result of changes in the rules (e.g., a wife's rights to her husband's property on his death changed by a new law) or in legal reasoning (e.g., a new local government land-use plan, or judicial abandonment of prior reasoning), or the ever-occurring transformations resulting from births, deaths, and divorces. Keeping the records of conclusions about title up-todate is a key element of such systems if trust in the accuracy of the recorded conclusions is to be fostered. It may be accomplished by placing the burden on interested private parties, disinterested private organizations (e.g., for-profit title insurance companies or otherwise insured legal experts in the USA), some part of government, or some combination (e.g., Ghana).

- Assurance for reliance on system errors: Insurance, or some other guarantee of, or mechanism for providing compensation or rectification is often provided for those who rely on what turn out to be errors in the system. Sometimes the compensation mechanism is provided by government, sometimes by private insurers; sometimes government does not compensate but provides a different solution - e.g., redistribution; and sometimes there is no recourse at all.

- Protection of land rights: Protection rests on the foundation of the other parts of the ecology. The functions may be accomplished through a single specialized body or a combination of

\footnotetext{
${ }^{23}$ As an example, apparently only about $30 \%$ of English land is so registered, and even that is often registered in ways that hide the true owners.
} 
informal and formal forums; administrative or judicial; government or private sector; local and community-based or distant and centralized, cheap or costly; it may be done periodically and all at once or episodically and individually. Without real and effective protection, land rights loose much of their certainty and, often, their value.

Thus, the environment in which land rights must be protected is complex, populated by interconnected domestic organizations and institutions, with quite variable configurations. It is also common even in highly developed, long-standing systems - for one piece or another of the system to be in transition from one type to another in order, ostensibly, to improve it from one perspective or another. Often, however, such changes benefit some at the expense of others (Kanji, N., Cotula, L., et al, 2005). All of these statements are true of the complex Ethiopian land rights protection ecology, including as it does, Federal, State and local levels.

\section{PROTECTION OF LAND RIGHTS IN ETHIOPIA: FINDINGS}

Mekelle University's recent land rights research, with IIED and $\mathrm{DfID}^{24}$, was concentrated in the State of Tigray, where systematic post-Derg land rights protection reforms were first undertaken in Ethiopia. The resulting 'Tigray Model' of universal rural land registration and certification has subsequently been the starting point for all the other States' current efforts (Adenew, B., 2005), though many changes and improvements are underway in those other States, and in Tigray, as well, in part as a result of the feedback from MU's research.

What did we find? Too much to report in a short paper like this, but examples of various strengths and weaknesses can be given. The

24 Mekelle University, Mekelle, Tigray, Ethiopia; International Institute for Environment and Development, London; funded by the United Kingdom's Department for International Development. For the full report, see Haile, M., Witten, W., et al, 2005. 
most general finding is that since $1989^{25}$ a multi-faceted and largely effective effort has been made throughout Tigray to create a configuration of inexpensive, local, practical institutions and organizations to protect land rights, one that could be and was put in place across the State expeditiously, uniformly, and with available resources.

It doesn't take very long to describe that remarkable achievement, compared with the pages and pages of more extensively detailed problems that follow, but in large measure the effort has been quite successful when considered as a comprehensive system. In terms of the ecology of land rights protection, we find:

Land Identification: When we look at the technology selected in Tigray for identification of a piece of land on registration forms and personal certificates, we find very low cost, locally available and locally well-understood choices: land is quantified using traditional measures (time required to plow) and demarcated primarily by the names of the family head, four neighbors, and a neighborhood within the village. Sometimes physical markers (most often stones) are also used. When large-scale registration was first undertaken anew (1996-1998), minimally trained high-school students (fulfilling their civilian national service) assisted. But the primary evidence of land rights came from local people, confirmed in open general meetings.

These choices of technology, understandably cost-based though they are, have consequences for the protection of land rights. In the positive, such land descriptions were and continue to be easy, cheap and quick to generate uniformly across the State ${ }^{26}$, and in most every-day situations, serve adequately. But, in the negative, such

\footnotetext{
${ }^{25}$ And before 1989 in areas controlled earlier by the Tigray Peoples' Liberation Front (TPLF) during its struggle against the Derg.

${ }^{26}$ In Amhara State a pilot project in four villages has tested GPS and other more expensive and more precise technologies. But, so far, these have not been extended beyond the pilot area, principally for two reasons: 1) the expense and 2) the fact that their use removes control from the local people to experts in more distant locations, one of the great and common dangers of 'modernizing' land rights protection (Adenew, B., 2005; Quan, J. and Toulmin, C., 2004).
} 
simple descriptions are of little use in the most common land disputes when they do occur - encroachments (e.g., plowing or grazing) by one farmer into the land of a neighbor. Evidence from the traditional witnesses who laid out the parcels is, therefore, still necessary when disputes over plot boundaries arise.

This, in turn, we found, has two corollaries. First, it corresponds to a difference in the way men and women tend to think about their land title certificates: Though men initially sought registration to mark the end of redistributions, and expect plot-incursion conflicts, they do not generally fear challenges to their 'title'. As a result, after the initial recording of title, the language men used to refer to their registration and certificates changed and did not reflect a continuation of high valuation. By contrast, women feel most threatened on fundamental title issues (and recent evidence indicates that they are, indeed, targeted in land title disputes more often than men, primarily because of their more limited defensive resources), and continue to highly value their title certificates.

Second, as the traditional witnesses age and die, landholders in some areas (i.e., Samre), including men, express an increasing reliance on, and valuation of their land registration certificates, and have begun demanding better land description technology. This is also occurring in areas where land values are rising (most notably in peri-urban $\left.\operatorname{areas}^{27}\right)$ and attendant disputes are also increasing.

These findings provide part of the support for the conclusion that, just as in richer countries, most land holders in Ethiopia do not value land rights protection on conceptual grounds, but, instead, on very functional grounds-grounds that often take some time to manifest themselves, or some particular change in the environment to be noticed. They also demonstrate that, especially for the citizens of a poor country, the cost of better quality government service - here more accurate measurement technology - is a very real barrier.

\footnotetext{
${ }^{27}$ There have long been more exact (and expensive) land identification technologies at use in urban areas, primarily theodolite and tape measure.
} 
Creation and allocation of rights: In Tigray, and elsewhere in Ethiopia, this niche in the ecology of land rights protection displays an appearance of simplicity because the Derg ${ }^{28}$ extinguished past rights and created a new set of simpler, locally rooted, uniform land rights granted by the State. As a result, inadequate consideration has been given to exactly how land rights actually arise and are allocated.

For example, after the EPRDF liberalized the very restrictive Derg landholding laws - allowing leases and sharecropping - many leaseholds were created anew. But in the Tigray land registration system no provision was made for registering the new leasehold and sharecropping rights, only the original State-granted rights. As is so often the case with economic actors, farmers then invented other forms of pseudo-registration, such as signing the leases before the head of the village council or a village Social Court judge and leaving a copy with that authority. Thus, when the formal system failed, the people created an informal system that did much of what they deemed important. ${ }^{29}$

The creation and allocation of land rights is further complicated by the fact that several land rights systems other than the rural land system actually persist side-by-side in Ethiopia today, e.g., the urban land system vs. the rural land system; rural communal vs. rural individual; and rural peasant vs. rural pastoralist vs. rural investor. As a result, conflicts arise at each of these interfaces when rights in the same land are recognized in the different but unconnected systems.

For example, investors in southeast Tigray were allocated (by village leaders, Wereda-level administrators, and a lease with the State Agriculture Bureau) 'unused' land in the Mehoni Plain. They borrowed heavily and invested in clearing the land for commercial

\footnotetext{
${ }^{28} \mathrm{Or}$, in areas under control of opposition movements, like the Tigray Peoples' Liberation Front (TPLF) in Tigray, the rights were effectively extinguished by both the Derg laws and the movements' enforcement.

${ }^{29}$ The Federal land law now requires leases be registered.

Proclamation NO. 456/2005, Article 6.6.
} 
farming. Then they discovered the land was registered in a separate registry $^{30}$ as communal grazing land for a group living in a neighboring village. When the dispute was administratively adjudicated at a higher level of government - the Zone that included both village areas - the land was reallocated to the use of the neighboring claimants. The investors were then given a different piece of land to clear and most went bankrupt.

The adverse effect of parallel land rights systems that is most obvious to urban-based researchers is at the urban vs. rural interface, the peri-urban areas. Because the urban and rural land rights systems are separate in Ethiopia, as a municipal area grows rural land is transferred into the urban system. The natural uncertainties of such transfers (i.e., differing evaluations and expectations) are compoundded by the 'ownership' of the land by the government, the lack of a clear set of rules for compensation when land and improvements are 'taken', the often limited capacity of local civil servants to follow available rules, and the coincidence that at exactly the time when rural citizens need their local government's protection of land rights, the land is transferred to the jurisdiction of a new, unknown and often more distant municipal government.

The result of all these factors is that the outcomes in 'takings' situations of all types, but particularly in the peri-urban areas, vary tremendously - a sure sign of a poorly functioning system. Complicating the picture even more, the holders of rural land near expanding municipalities have invented clever $^{31}$ defensive strategies that further enlarge the variance in outcomes, making it hard to tell

\footnotetext{
${ }^{30}$ Similarly, reforestation and natural regeneration areas are usually described, together with agreed management rules, in written documents kept in a separate registration system.

31 'Moon houses' and even 'moon churches', appearing over night on urban sized plots of rural land adjacent to municipal boundaries, in some cases have been construed as entitling the owner of the house to rent the plot from the municipality under the urban land leasing system, thus enabling the rural land holder to "sell" land, which is Constitutionally prohibited. However, most often the municipality knocks the illegal moon houses down, though not the moon churches, compensates the rural owner with a small urban sized plot around the family home, and then leases the land to the many urban land seekers.
} 
at any particular time whether the municipal administration or the land holders are more successful.

But a much larger scale weakness of the post-Derg allocation of land rights resulted from increasing population that caused demand for rural land to far exceed local supplies. Thus, as mentioned in the Introduction, not many years after the last land redistribution the Constitutional right to obtain and hold rural land could no longer be fulfilled for youth coming of age and for adults returning to Tigray villages. ${ }^{32}$ Though serious efforts were made in villages to discuss the problem, prioritize those without land, and find unused land within the village boundaries for allocation, the problem grew inexorably worse.

In addition to the severe limitations of already too small family holdings, only very small amounts of land were returning to the local government for reallocation - primarily when villagers with land died without eligible heirs. ${ }^{33}$ And because the problem existed at the local level, as a result of the policy choices that emphasized local control, no solution could be found. Eventually, however, when the problem reached a politically sensitive extent, with a large portion of rural people State-wide being landless, new land was located - a good example of different solutions being available to different scales of government.

The largest source of new land has now come from higher levels of government searching larger areas for unused land. In the western 'borderlands' of all of the large highland States, great swaths of land have been located that have never been settled, primarily because of malaria. With improved malaria control these areas have been opened to voluntary settlement, including the slow and sometimes clumsy establishment of the same local institutions and organizations to protect land rights as are found in the highlands.

\footnotetext{
${ }^{32}$ Returning from, among other places, forced resettlement by the Derg in southern Ethiopia, refugee camps in the Sudan, and the TPLF's combatant ranks.

${ }^{33} \mathrm{~A}$ smaller source of new land to meet demand has been the enforcement of two rights in rural land reserved to the State by the Federal land laws, triggered when landholders abandon or mismanage their land. See Transformation, below.
} 
Transformation of rights: Just as the origins and allocation of land rights were over-simplified, transformation and reallocation of land rights have received insufficient consideration in Tigray and elsewhere in Ethiopia in the post-Derg period. At the village level, transforming events, such as births, deaths, marriages, divorces, determinations of incapacity, loans, and myriad others, are well known. But until 1996, little of this information was systematically noted in any permanent form. And if it was, for example, written down, the records were scattered in a variety of traditional and more-modern individual, religious, administrative and judicial systems. The only place the information came together and was tied to land was in people's minds, and often they had different and conflicting interests and agendas and drew different conclusions. The uncertainty that resulted caused disputes to slowly become more common again until, in 1996, the new system was put in place, see Registration of Title, below.

But, as well as these record-keeping issues, transformation of land rights also has direct ramifications. For example, the Federal land laws identify two special rights in all rural land, allocate them to the State government, and mandate that the States enforce them. First, the State should take the land of rural land holders who leave their land for more than a period of years fixed by the State. ${ }^{34}$ Second, the State should take the land of anyone who has 'environmentally

${ }^{34}$ FDRE proclamation No. 456/2005, Article 9.1. Exceptions to this rule in the Tigray State proclamations, currently highly criticized by rural communities and being considered for State legislative change, protect the rights of some ex-fighters and early urban migrants to maintain rural land even though they live in urban areas. In Tigray, the period is two years if traditional farming technology is in use, ten with modern. In Amhara the period has now been set at twenty years. The difference seems to correlate most strongly with differences in unfilled demand for rural land. The assumption behind this right seems to be that anyone able to stay away from their village for the specified number of years has another viable source of income and their land should be made available to those with no land and no other source of income. In cases where this is demonstrably not the case (i.e., Ethiopians detained in Eritrea during the recent war), the rule has not been applied. There is a correlation between Tigray's 2 year loss-through-absence provision and a limitation on leasing rural land that limits small holder lease periods to 2 years for "traditional technology" and 10 years for "modern technology". Unfortunately, the two quoted terms are not defined. 
mismanaged' their land. ${ }^{35}$ In each of these cases, the land taken returns to the local village council for reallocation to the landless.

In determining whether the land has been 'left' or 'environmentally mismanaged', the local village government's administrative discretion plays a major role. It can, therefore, be either helpful, harmful, or some mixture. For example, there is some evidence that 'environmental mismanagement', even with large extension programs to help landholders comply, allows too much room for traditional biases and has been misused to take the land of people a local government wants to punish (Hoben, A., 2001; Adal, Y., 1997; Debele, B., 1997; Ege, S., 1997). Interestingly, the State cabinet-member who oversees the Tigray State land rights system ${ }^{36}$ points out that Tigray has never allowed this form of land reallocation, specifically because it is too open to such mischief. ${ }^{37}$

A different result from administrative discretion is found when considering the second State right, at least in Tigray. There women often move to their husband's village where there is no land to be allocated to them. A strict application of the land-abandonment law would probably dictate that these women lose any land they have in their home village and become landless. However, one of the common outcomes in Tigray villages has been to allow women to hold land in their home village until they receive land in their new village. This is generally considered a beneficial outcome, despite pressure from the landless for land.

A related, but as yet unquantified, transformation effect has been more difficult to study because it occurs over a longer period of time. As noted in the Delineation section above, the right to inherit land is also subject to limitation in State Constitutions and procla-

\footnotetext{
${ }^{35}$ FDRE proclamation No. 456/2005, Article 10.1.

36 Now EPLAUA, Environmental Planning, Land Administration, and Use Authority. In 2004, amendments to the Tigray State land proclamation reorganized the role of government in land administration, creating this dedicated Authority as part of the changes to correct past deficiencies, modeled at least in part on the Amhara changes to the 'Tigray Model'.

${ }^{37}$ Personal communication, February 2005.
} 
mations. In Tigray, for example, where land pressure is very high and many family holdings are already below the size necessary to produce a living, the right to inherit has been limited by social welfare principles applied by the local government in accordance with State regulations. Principal among these are that not all children have equal rights to inherit; that children with another source of income shall not inherit, even if that means there are no qualified heirs; and that children who have stayed on the land to help the parents farm shall have a better right to inherit.

One result of this intersection of principles is that women who marry men with land and income in another village, and thus do not stay to help their parents farm, are less likely to inherit than their brothers, even though they usually cannot obtain their own land in their husband's village. Thus, despite the official policy and laws providing equal rights to land to men and women, despite effective implementation of those policies when there was adequate land, and even despite the local governments' efforts to allow women to keep their own land in their home village, land holdings may slowly become concentrated in male hands. This is a good example of formal and informal institutions interacting with what appear to be entirely unexpected and unintended consequences.

Preservation of evidence: In an impoverished agricultural society like rural Ethiopia, efforts to improve preservation of evidence include a wide range of administratively-complex undertakings, from general education so people can read and value documents to patching the roof on the agricultural extension agent's office to improving record keeping in the courts, and much more. Perhaps most important, however, is to create the understanding that these pieces must all be tied together in one way or another.

It is not an accident that the demand for better preservation of landrights evidence grew with every passing year after the last land distribution occurred. As events affecting land rights accumulated over time without a systematic way to connect them to resolution of disputes, uncertainty of outcomes increased. Thus, it is that the introduction in 1996 of a Statewide land title registration system in 
Tigray was conceptualized as a way to preserve evidence in a simplified form - as opposed to a way to record legal conclusions based on evidence preserved in separate archives. Those who set up the system did not adequately consider that changing laws (e.g., concerning who inherits) affect how the legal conclusion of title is determined, and may require reassessment of the evidence of original or transforming events.

This misconceptualization led to some of the weaknesses of the Land Title Registration system. One of these is the failure to adequately improve the preservation of the underlying documentary evidence on which the legal conclusions of title are based.

Registration of 'title': Between 1996 and 1998 a new system designed to increase the security of rural land was designed and put in place throughout Tigray State. Of particular importance was the policy choice to accomplish this by building on other aspects of local governance that had been subject to vigorous improvement under the TPLF even during the Derg, including village councils and the judiciary.

Using simple forms, the traditional land description technology noted above, the local language, minimally trained technicians, negligible per-family charges (US $\$ 00.25$ for a Certificate), and a review of all evidence of then existing land rights, legal conclusions about title were determined and recorded at the village level. The record books were kept in the local village government offices (either the Council President's office or the Agricultural Extension Agent's office, whichever seemed better protected against rain, rodents, mold and people) and a Certificate was provided for each family. The entire system was administered locally by the village council, with planning and oversight from more distant levels of government at the Wereda (County) and State levels.

On the positive side, the speed and evenhandedness of implementation across the entire State, and its acceptance by the people with very little controversy, stand out. The source of the 
systems strength most often mentioned by farmers was that it was established as part of 'their' existing effective local government.

Unfortunately, on the negative side, issues that a more thorough study of the ecology of land rights protection might have made clear were not adequately addressed. Most importantly, no provision for keeping the written records of the legal conclusions about title upto-date was institutionalized. After only a few years, many of the records of title became unreliable. There is conflicting evidence as to whether up-dating was countenanced in Tigray (though it is now clearly on the agenda in all State programs, with USAID assistance focused on it). A second problem -that the registration and certification forms ran out and were not resupplied-compounded the problem.

These systematic failures would have most adversely affected women, particularly on divorce, because of the then State rule (clearly derived from traditional practice, and now changed by Federal law ${ }^{38}$ ) of registering and certifying a family's land rights in the name of the head of the family - a male if present. Upon divorce, fairly common in highland Ethiopia, no new certificate or registration page in the woman's name was issued. Had the records been the sole source of land rights, women might have lost their land, as has been well documented during formalization of land rights systems in other countries (Quan, J. and Toulmin, C., 2004).

But because the land title registration system had been established as part of the existing relatively effective local government system, administrative discretion again provided a solution to the potentially harmful consequences of these apparently unforeseen events. As a result, we found no evidence that women's rights to their share of their family's land were ever compromised as a result of this failure.

Assurance for reliance on system errors: In Ethiopia, there is no public (as in Europe) or private (as in the USA) provision for insurance for those who rely on errors (e.g., out-of-date or incorrect

\footnotetext{
${ }^{38}$ Proclamation No. 456/2005, Article 6.4.
} 
records) in the rural land rights protection system. Instead, because both the allocation and protection systems are nearly completely local, there are very few rural landholders who do not reside where their land is, and information is easily available, the community provides assurance, at least to community members.

Thus, in many cases, as in the case of divorced women noted above, the local councils were able to address unforeseen problems through administrative action, providing a kind of assurance system. It is this last finding that has required couching the overall research results as: a simple inexpensive local registration system can work well, even with major oversimplifications, if it is established within an existing system of effective local governance. ${ }^{39}$ This is the reason the adjustment of the 'Tigray Model' following the Amhara State experience is being watched closely.

But, unfortunately, assurance and administrative discretion have two sides. We also found cases where local village councils colluded with a non-governmental credit association in the use of the threat of loss of land rights to enforce credit repayment. This is, of course, formally prohibited because mortgages, and transfers due to foreclosure, are specifically banned by the Constitution for the specific policy objective of ensuring that rural farmers do not lose their land through default on loans.

However, we also found another of the tools of good governance at work: oversight. When Wereda (County) and State-level administrators learned of the illegal collusion they promptly reversed the local decisions and instituted further training for local government administrators. Similar oversight results, as with several changes noted above induced by the Federal land laws, were found in other cases where what State and local administrators thought were

\footnotetext{
${ }^{39}$ What is a system of effective local government? This is a good but complicated question, unfortunately far beyond the limitations of this study. The term is used here simply to mean a system of local government that effectively solves most problems that arise in the community in a way the community accepts, and as such, the term has the weakness of being suspiciously tautological.
} 
innovative solutions turned out to be ill-advised, or plainly illegal, and were corrected.

Are all such problems corrected through administrative and legislative solutions? Clearly not. Which leads us to consider the full range of correctives.

Protection of rights: Particularly for the poor, protection of land rights depends upon local systems. Protecting land rights from private or public attacks can be expensive, mounting in cost as distance, time away from home, and the need for expertise increase. One reason people in Tigray give for favoring local administrative solutions is that through them the government subsidizes the expense of enforcement. Of course, where the local government is the problem, as in the case mentioned above of collusion with debt collectors, local relief may not be available.

In Tigray, and subsequently elsewhere in Ethiopia, a sustained government effort has attempted to supplement more traditional dispute resolution methods. Prior research by Mekelle University Law Faculty into the village Social Courts and Wereda (District) Courts compliments its land research and underscores both the popularity and the weaknesses of the dispute resolution options available to rural landholders.

Thus, rural land rights disputes are usually resolved within the village using a) traditional social dispute mechanisms (e.g., elders and/or those witnesses who participated in the last land distribution); b) local government administrative dispute resolution mechanisms, or c) the village Social Court - a 'hybrid' ${ }^{40}$ judicial system.

\footnotetext{
40 'Hybrid' because the people elected locally to serve, voluntarily and without pay (until July 2005, when they were voted small reimbursements), as social court judges are much like the kinds of people who serve as mediators in the traditional dispute resolution forums and, as traditionally, they encourage parties to settle disputes amicably before eventually exercising their authority to decide the case; yet the social court also operates with a clear set of rules of procedure and a simplified version of the same law applied in higher courts, and there is an appeal to the Wereda court.
} 
These dispute resolution mechanisms are all within the village and therefore are relatively inexpensive to access; but each also has its problems and limitations. For example, the traditional systems are, as almost the world over, sometimes biased in favor of men or the powerful. When the administrative systems err, formal appeal can be difficult because administrative law is a very under-developed, and even less-utilized, area of Ethiopian law. And the village Social Court, because it applies somewhat more technical rules with less training, is often perceived as less reliable.

All three local forums may also be subject more generally to local community pressures, political pressure, abuse of power, and corruption. It is this which makes the availability of appeal from the Social Court to the Wereda (District) Court, away from village forces, very important. But while that appeal is necessary, it is, unfortunately, not sufficient: for the poorest the extra cost favors the rich. For all of these reasons together, forum shopping among the three can be an issue. Though the hierarchy of jurisdiction is clear, with each party able to opt out ${ }^{41}$ of the traditional in favor of the administrative, and with the administrative giving way to the judicial, that ultimate step can favor the rich. Thus, though efforts have been made to balance the attributes of the different forums, the balance is not yet completely satisfactory.

In any case, a threat to land rights that requires enforcement is costly and uncertain for the poorest, those already living very much on the edge. Defending rights requires and taxes scarce resources. And there is, for example, now at least anecdotal evidence in Tigray that women's land rights are attacked more frequently than men's because women have fewer resources available for defending.

These considerations have lead to discussions ${ }^{42}$ about how to strengthen subsidized administrative dispute resolution, while at the same time providing more oversight. Getting the balance right

\footnotetext{
${ }^{41}$ Of course, rights to 'opt out', as with Ethiopia's Sharia Courts, must be known and those with the rights must be free and able to use them.

${ }^{42}$ Personal communications with the Tigray State cabinet member overseeing land issues, February and July, 2005.
} 
requires constant attention as institutions and organizations evolve. At this time, throughout Ethiopia these issues appear to be high on the agenda of the government but good information about how the systems are working, or not working, is not always available and solutions, as in every society, are often partial and subject to further adjustment.

\section{CONCLUSION}

Several different types of conclusions may be drawn.

Systematically, we can certainly conclude that international human rights instruments, per se, have little direct impact on domestic land rights. Protection of land rights takes place in a complex and constantly evolving environment of interconnected domestic institutions and organizations. The public legislative, administrative, and judicial functions, as well as the more obvious private transactions, all play a role in protecting land rights. In Ethiopia's Federal system, this ecology also includes the diversity of the Federal level and multiple States. Changes in the ecology occur constantly as a result of learning, exercise of appeals, democratic forces and transitions, 'civil society' activism, and, unfortunately, violence; often both the land rights ecology and the effects of changes to it, are not well understood and usually changes benefit some people more than others.

Still, there are some principles which can be abstracted because in many cases the domestic institutions and organizations have wellknown - though not well-calibrated and easily-achieved - general balance points and trade-offs. For example, we have seen the strengths of local government from high-quality and low-cost information versus their susceptibility to discrimination and abuse of power, whether intended or not. And we have seen how larger scale solutions are only possible at larger scales of government, as with the opening of new State or national lands to settlement, with the unfortunate inverse correlation of larger scales of government being further removed from the concerns of the people. Yet, while 
interesting, such abstractions don't help us understand the complexity of improving the land rights protection system.

And it can not be denied that there is much room for improvement in Ethiopia. In fact, we have seen that many changes are indeed currently underway as a result of both State and Federal initiatives. However, these efforts to improve, as everywhere, require an understanding of the complexity and interdependent nature of the system; collection of good quality information about current affairs; mechanisms to inform and train the huge number of politicians, civil servants, and judges involved in legislation, administration and judicial review; and frequent exercise of those systems, like the judiciary, that are internally designed to improve through the exercise of appeals.

Thus, within the hard realities, protecting land rights is not very different from protecting other human rights that can only effectively be protected through domestic systems. Progress is slow and requires great effort at the Federal, State and local levels. Cost is always an issue. How the system should be changed is always subject to debate and - particularly in poor countries constantly bombarded with "experts" from different countries, with their insular knowledge of one or a few ways of doing the thing - that debate is often a confusing and frustrating milieu, sometimes undermined by piecing together contrary methods that don't work together.

So, instead of ending with abstractions about land rights protection, on this particular occasion I would like to consider the specific efforts of the Mekelle University Law Faculty (MULF) towards improving human rights protection in general and land rights in particular. By considering these specific efforts, we may gain a perspective on how the protection of human rights in general may be improved.

From its inception MULF has undertaken practical field research on the strengths and weaknesses of human rights protection; formulated, funded and provided continuing education and shorter tailored 
trainings for civil servants and Social Court and Wereda Court judges; provided advisory services and legislative drafting services for the State parliament; and engaged regularly with all these organizations through workshops and performance reviews.

But this is not enough. Citizens, too, have a role to play and an obligation to do so. Many of the systems by which we expect human rights protection to be improved require that citizens exercise the system. And perhaps here a topical analogy to the right to free and fair elections is appropriate. As the Carter Center, in its Final Statement on the May 2005 Ethiopian elections concluded, "If parties decide not to file court appeals, the [National Election Board of Ethiopia's] announced results should be accepted as final and legitimate." ${ }^{43}$ Just as in challenges to elections in Florida, USA, or in Birmingham, UK, or in the Ukraine, there are, in the end, only the existing domestic institutions and organizations to turn to for protection of human rights. If citizens do not exercise the appeals by which much improvement, by design, must occur, then those improvements will not happen, and society will suffer.

Of course, that so many of the citizens of Ethiopia are as poor as they are means that they need assistance to exercise the systems. Which is why the MULF Legal Aid Clinic, the first in Ethiopia based in a university, and housed in the same off-campus building as the MULF Human Rights Center, provides legal services to poor land holders.

Finally, that some States in Ethiopia are slower, and clumsier, than others to improve should not surprise Europeans any more than it does this American author. There are plenty of well-known examples among the States of the European Union (e.g., the results of Italy's late Twentieth Century devolution of power to regional states, see Putnam, R., 1993). And that is why MULF also, through every possible means, from participating in the design of a USAID land rights security project to participating in the Capacity Building Ministry's committee to strengthen legal education (including

\footnotetext{
${ }^{43}$ The Carter Center, September 15, 2005, www.cartercenter.org/documents/2199.pdf, p.3.
} 
research) in all of Ethiopia's law schools, seeks to improve and spread its broad approach to strengthening the Ethiopian domestic institutions and organizations that are all that can, in the end, protect human rights.

Thus, I would like to take this opportunity to encourage MULF to continue and strengthen all these programs, and to ask that those who support them in these endeavors continue their vital support.

\section{BIBLIOGRAPHY}

ADAL, Y. (1997) Rural land holdings readjustment in West Gojam, Amhara Region, a paper presented at the Workshop on Access to Land and Resource Management in Ethiopia, organized by the Land Tenure Project of Addis Ababa University, Nov. 28-29, Addis Ababa.

ADENEW, B. and ABDI, F. (2005) 'Research Report 3, Land Registration in Amhara Region, Ethiopia', Securing Land Rights in Africa Series, IIED, London.

ATWOOD, D. (1990) 'Land registration in Africa: the impact on agricultural production', World Development 18 (5).

BARROWS, R. and ROTH, M. (1990) 'Land tenure and investment in African agriculture: theory and evidence', The Journal of Modern African Studies 28 (2).

BAUER, D. (1972) Land, Leadership and Legitimacy Among the Inderta Tigray of Ethiopia, Ph.D. Dissertation, UMI, Ann Arbor.

BRUCE, J. and MIGOT-ADHOLLA, S. (eds.) (1994) Searching for Land Tenure Security in Africa, Kendall-Hunt, Iowa.

BRUCE, J., HOBEN, A. and RAHMATO, D. (1994) 'After the Derg: An Assessment of Rural Land Tenure Issues in Ethiopia', in RAHMATO, D. (ed.) (1994).

COUSINS, B. and CLAASSENS, A. (2006) More than simply 'socially embedded': recognizing the distinctiveness of African land rights, Keynote address, Montpellier, May 17-19, 2006.

DEBELE, B. (1997) Review of Land Distribution Procedures in Tigrai and Amhara Regions and Proposals for Study in Oromia Region, Part 1 - Review of Experiences, a paper for the Land Use Planning and Resource Management Project in Oromia Region, GTZ, Addis Ababa. 
DEININGER, K. (2003) Land Policies for Growth and Poverty Reduction, Oxford University Press and The World Bank, Oxford and Washington.

DEININGER, K., et. Al. (2003) 'Tenure Security and Land-Related Investment: Evidence from Ethiopia', World Bank Policy Research Working Paper 2991, The World Bank, Washington.

DEININGER, K., et. al. (2003) 'Market and Nonmarket Transfers of Land in Ethiopia: Implications for Efficiency, Equity, and Nonfarm Development', World Bank Policy Research Working Paper 2992, The World Bank, Washington.

EGE, S. (1997) 'The Promised Land: The Amhara Land Redistribution of 1997', Working Papers on Ethiopian Development No. 12, Norwegian University of Science and Technology, Center for Environment and Development, Trondheim.

ETHIOPIAN ECONOMIC ASSOCIATION/ETHIOPIAN ECONOMIC POLICY RESEARCH INSTITUTE (EEA/EEPRI) (2002) Land Tenure and Agricultural Development in Ethiopia, EEA/EEPRI, Addis Ababa.

GEBREMEDHIN, B., PENDER, J., et al (2002) 'Policies For Sustainable Land Management In The Highlands Of Tigray, Northern Ethiopia', in EPTD Workshop Summary Paper No. 14, IFPRI/ILRI, Washington/Nairobi.

HAILE, M., WITTEN, W., et al (2005) 'Research Report 2, Land Registration in Tigray, Northern Ethiopia', Securing Land Rights in Africa Series, IIED, London.

HENDRIE, B. (1998) unpublished DRAFT Ph.D. Dissertation, presented at a Mekelle University seminar, Mekelle, Tigray, Ethiopia.

HOBEN, A. (1995) 'Paradigms and politics: The cultural construction of environmental policy in Ethiopia', World Development, Vol. 23 Issue 6.

HOBEN, A. (2001) Ethiopian Land Tenure Revisited: Continuity, Change And Contradictions, a paper presented at the IDR Conference on Land Issues, April 6-7, Addis Ababa.

HOLDEN, S. and YOHANNES, H. (2001) 'Land Redistribution, Tenure Insecurity, And Intensity Of Production: A Study Of Farm Households In Southern Ethiopia', CAPRi Working Paper No. 21, IFPRI, Washington.

KANJI, N., COTULA, L., et al (2005) Research Report 1, Can Land Registration Serve the Poor and Marginalized Groups? Summary Report, IIED, London.

KIDANU, A. and ALEMU, T. (1994) 'Rapid Population Growth and Access to Land: Coping Strategies in Two PAs in North Showa', in RAHMATO, D. (ed.) (1994). 
LUND, C. (1998) Law, Power and Politics in Niger - Land Struggles and the Rural Code, LIT Verlag, Hamburg.

LUND, C. (2000) African land tenure: questioning basic assumptions, Drylands Issue Paper No. 100, IIED, London.

MARCUS, H. (1994) A History of Ethiopia, University of California, Berkeley.

MERSHA, G. and wa GITHINJI, M. (2005) 'Untying the Gordian Knot: The Question of Land Reform in Ethiopia', ISS/UNDP Land, Poverty and Public Action Policy Paper No. 9.

NORTH, D. (1990) Institutions, Institutional Change and Economic Performance, Cambridge University Press, Cambridge.

OSTROM, E. (1998) Governing the commons: the evolution of institutions for collective action, Cambridge University Press, Cambridge.

PUTNAM, R. (1993) Making Democracy Work, Civic Traditions In Modern Italy, Princeton University Press, Princeton.

QUAN, J. and TOULMIN, C. (2004) 'Formalizing and Securing Land Rights', Overview Paper, Working Group 1, Land in Africa Conference, IIED, London.

QUAN, J., TAN, S., and TOULMIN, C. (2005) Land In Africa: Market Asset or secure livelihood?, Proceedings and summary of conclusions from the Land In Africa Conference held in London November 8-9, 2004.

RAHMATO, D. (ed.) (1994) Land Tenure and Land Policy in Ethiopia After The Derg, Norwegian University of Science and Technology, Center for Environment and Development, Trondheim.

RAHMATO, D. (1994) 'Land Policy in Ethiopia at Cross-roads', in RAHMATO, D. (ed.) (1994).

RAHMATO, D. (1999) 'Revisiting the Land Issues: Options for Change', Economic Focus, Vol. 2, No. 4, Ethiopian Economic Association, Addis Ababa.

SHITAREK, T., et al (2001) Strengthening user-rights over local resources in Wollo, Ethiopia, Drylands Programme Issue Paper No. 103, IIED, London.

SIDA-Amhara Rural Development Programme (2003) SARDP III, Support to Environmental Protection and Land Administration and Use Agency, 2004-2007, Draft of September 2003, Bahir Dar. 
TEKLU, A. (2005) Research Report 4, Land Registration and Women's Land Rights in Amhara Region, Ethiopia, Securing Land Rights in Africa Series, IIED, London.

TEKLU, T. (2003) Rural Lands and Evolving Tenure Arrangements In Ethiopia: Issues, Evidences And Policies, FSS Discussion Paper No. 10, Forum For Social Science, Addis Ababa.

WARDEN, G. (2001) The Ethiopian Model, Geophilos, Spring. 